\title{
Pengaruh Kehalusan Bahan Dan Lama Ekstraksi Terhadap Mutu Ekstrak Tempuyung (Sonchus arvensis L.)
}

\section{Effect Fineness Extraction of Materials and Old Quality Extract (Sonchus arvensis L.)}

\section{Feri Manoi}

\section{Balai Penelitian Tanaman Rempah dan Obat} Email: fmanoi@yahoo.com

\begin{abstract}
Utilization of medicinal plants both for health and treatment increased at this time. Number of Traditional Medicine Industry (IOT), Small Industries Traditional Medicine (IKOT) and Industrial Appliances (PIRT) is increasing. Thus the demand for raw materials is increasing, one of which is tempuyung. Good quality raw material in the form of crude drugs and extracts need to be considered as related to the efficacy and quality of products for further processing. The study aims to determine the effect size and the old material extraction to the yield and quality of the extract. Activity consists of two sub-activities (1). How to drying (a) the sun covered with black cloth, (b) the sun combination of tools, and (c) drier. Sub-activities (2) extraction technique which consists of two factors: the fineness of materials (20,40 and 60 mesh) and the second factor is the length of the extraction (2, 4, and 6 hours). The study design using factorial completely randomized design with three replications. Parameter observations consisted of yield bulbs, phytochemical screening, quality characteristics, extract yield, and quality extracts. The results showed levels of water extract Sonchus arvensis L. greater than the levels of alcohol cider. Quality simplicia Sonchus arvensis L. dried using a dryer is not different from the quality of the dried under the sun. Fineness of materials and time of extraction affects the yield of the extract Sonchus arvensis L
\end{abstract}

Keywords: Subtlety material, extraction, quality

Diterima: 12-01-2015 : disetujui 07-02-2015

\section{PENDAHULUAN}

Indonesia memiliki 40.000 spesies tumbuhan berbunga yang tersebar pada lebih dari 17.000 pulau (Rivai dan Anggadiredja, 1995), dari jumlah itu 1.070 spesies merupakan tanaman obat (Heyne, 1987); 1.000 tanaman penghasil zat racun; 50 spesies rempah dan 50 spesies atsiri yang diekspor. Menurut Jafarsidik (1999) tanaman obat yang terdaftar di formasi hutan jumlahnya 153 famili dan diantaranya terdapat 59 famili dalam bentuk pohon. Sedangkan menurut Eisai (2.000) terdapat \pm 7.000 spesies tumbuhan dihutan-hutan Indonesia yang diketahui berpotensi sebagai bahan obat, dari jumlah itu 940 spesies telah diindentifikasi dan 283 telah digunakan secara rutin dalam industri obat tradisional.

Penggunaan tanaman obat untuk kesehatan telah berlangsung lama sejalan dengan perkembangan peradaban manusia. Peningkatan penggunaan tumbuhan obat untuk kesehatan maupun 

pengobatan semakin kelihatan pada satu dekade terakhir. Data WHO menunjukkan bahwa perdagangan herbal dunia telah mencapai nilai 12-15 miliar USD setiap tahunnya pada tahun 2001, dan saat ini dilaporkan mencapai 60 miliar USD. Volume perdagangan tanaman herbal dalam bentuk jamu di Indonesia dan ekspor terbatas keluar negeri mencapai angka 8 triliun rupiah pada tahun 2005, meningkat menjadi 10-11 triliun rupiah pada akhir tahun 2010. Sampai tahun 2010 tercatat jumlah industri di bidang obat tradisional sebanyak 1908 terdiri dari 79 Industri Obat Tradisional (IOT), 1413 Industri Kecil Obat Tradisional (IKOT) dan 416 Industri Rumah Tangga (PIRT).

Pada tahun-tahun mendatang kebutuhan bahan baku tanaman obat diperkirakan akan terus meningkat, terutama berkaitan dengan adanya program pemerintah untuk memasukkan penggunaan tanaman obat dalam pelayanan kesehatan formal. Kebijakan tersebut diterapkan melalui Peraturan Menteri Kesehatan (Permenkes) Nomor 003/Menkes/Per///2010 tentang program Saintifikasi Jamu, yaitu upaya dan proses pembuktian ilmiah jamu melalui penelitian berbasis pelayanan kesehatan. Tujuan utama dari program Saintifikasi Jamu ini adalah menjadikan layanan kesehatan lebih terjangkau bagi seluruh lapisan masyarakat (Trihono, 2011).

Peningkatan kebutuhan dan permintaan tumbuhan obat perlu mendapat perhatian mengingat sebagian besar pasokan tumbuhan obat sampai saat ini masih menggantungkan pada tumbuhan yang dipanen langsung dari habitat alam, atau yang sering disebut penambangan hasil dari alam. Menurut Badan POM (2006), 283 jenis tanaman obat telah diregistrasi untuk penggunaan obat tradisional, 180 jenis di antaranya merupakan tanaman obat yang masih ditambang dari hutan. Berkaitan dengan pengembangan program saintifikasi jamu, Kementerian Kesehatan telah menetapkan sebanyak 55 jenis tanaman yang nantinya dipergunakan dalam pengobatan di Pusekesmas, salah satunya adalah tanaman tempuyung. Tanaman tempuyung (Sonchus arvensis L.) merupakan tumbuhan herba yang umumnya tumbuh liar di tempat terbuka, tebing, dan pematang sawah pada ketinggian tempat 50-1650 m dpl (Depkes, 1977). Tanaman tempuyung dikenal sebagai penghancur batu ginjal (litotriptik) atau anti kalkulus urinare (Sardjito et al., 1964 dalam Surahso et al., 1993). Selain itu daun tempuyung juga dapat digunakan sebagai obat asma, bronkhitis, batuk, insomnia, bengkak dan tumor (Lie, 2002). Senyawa kimia yang terkandung di dalam daun tempuyung yaitu silika, kalium, flavonoid, kalsium, magnesium, natrium, taraksasterol dan asam fenolat, (Pramono et al., 1993). Senyawa flavonoid yang terdapat pada daun tempuyung merupakan senyawa aktif yang kompleks. Menurut Katno (2004), senyawa aktif yang termasuk golongan flavonoid yang terdapat dalam tempuyung adalah apigenin 7glucoside and luteolin 7-glucoside. Kedua bahan aktif tersebut berfungsi sebagai peluruh batu ginjal dan diuretik. Tempuyung termasuk salah satu simplisia yang ditetapkan sebagai calon obat fitofarmaka.

Permasalahan yang masih perlu ditangani antara lain teknologi penanganan hasil panen dalam rangka mempertahankan mutu bahan sebelum dan sesudah diolah lebih lanjut. Salah satunya adalah dalam menyiapkan bahan baku dalam bentuk simplisia dan ekstrak. Mutu simplisia secara visual dapat dilihat dari warna dan aroma, karena persyaratan simplisia yang baik adalah warna dan aroma tidak boleh jauh dari aslinya. Selain itu penanganan terhadap bahan setelah dipanen kurang diperhatikan sehingga mutu/kualitas dari bahan menurun. Mutu ekstrak dipengaruhi oleh kualitas simplisia dan proses ekstraksi. Ekstraksi merupakan metode pemisahan dimana komponen-komponen terlarut suatu campuran dipisahkan dari komponen yang tidak larut dalam pelarut (Hui, 1992). Demikian halnya degan ekstrak dimana mutu ekstrak sangat dipengaruhi oleh mutu simplisia. Selain mutu simplisia, mutu ekstrak juga dipengaruhi oleh kehalusan bahan, jenis pelarut, lama ekstraksi, konsentrasi pelarut dan suhu. 


\section{METODE}

Penelitian dilaksanakan di Laboratorium Pengujian Balai Penelitian Tanaman Rempah dan Obat, Bogor pada bulan Juni-September 2013. Bahan baku menggunakan tempuyung yang diperoleh dari Kebun Percobaan Manoko, Lembang. Bahan kimia terdiri dari etanol teknis dan etanol pa serta bahan kimia lainnya untuk analisis mutu. Peralatan yang digunakan adalah timbangan, peralatan pencucian, alat pengering, penepung, ekstraktor dan alat-alat gelas lainnya untuk analisis mutu simplisia dan ekstrak.

Tahapan kegiatan terdiri dari penyortiran, pencucian, penirisan, pengeringan, penyerbukan, ekstraksi dan analisis mutu simplisia dan ekstrak. Penelitian terdiri dari dua sub kegiatan yaitu 1) Cara pengeringan yang terdiri dari: matahari, matahari ditutup kain hitam, dan alat pengering. 2) ekstraksi yang terdiri dari dua faktor, yaitu a) Kehalusan bahan: 20, 40 dan 60 mesh, dan b) Lama ekstraksi: 2, 4 dan 6 jam. Rancangan penelitian menggunakan Rancangan Acak Lengkap Faktorial dengan 3 ulangan. Parameter pengamatan meliputi: rendemen simplisia, skrining fitokimia, karakteristik mutu, serta rendemen dan mutu ekstrak.

\section{HASIL DAN PEMBAHASAN}

\section{Mutu Simplisia Tempuyung}

Pengeringan adalah suatu cara pengawetan atau pengolahan pada bahan dengan cara mengurangi kadar air, sehingga bahan tidak mudah rusak dan tahan disimpan dalam jangka waktu yang lama. Pada saat proses pengeringan terjadi penguapan air sehingga kadar air dan reaksi-reaksi zat aktif dalam bahan akan berkurang. Pengeringan dapat menyebabkan perubahan-perubahan hidrolisa enzimatis, pencokelatan, fermentasi dan oksidasi sehingga suhu maupun kebersihan perlu diperhatikan. Suhu pengeringan untuk tanaman obat pada umumnya berkisar antara $40-60^{\circ} \mathrm{C}$ dan simplisia yang dihasilkan memiliki kadar air berkisar antara 5-10\%.

Tabel 1. Pengaruh cara pengeringan terhadap karakteristik mutu simplisia tempuyung

\begin{tabular}{lccc}
\hline \multirow{2}{*}{ Parameter/Parameters } & \multicolumn{3}{c}{ Hasil Pemeriksaan/Result } \\
\cline { 2 - 4 } & Matahari & Matahari ditutup kain hitam & Alat \\
\hline Kadar air (\%)/Water content (\%) & 6,67 & 8,26 & 8,80 \\
Kadar abu (\%)/Ash content (\%) & 14,93 & 13,12 & 14,72 \\
Kadar abu tak larut dalam asam (\%) & 1,74 & 0,60 & 0,24 \\
Kadar sari air (\%) & 27,72 & 26,73 & 28,16 \\
Kadar sari alkohol (\%) & 9,01 & 8,11 & 6,77 \\
Rendemen simplisia (\%) & 10,60 & 15,44 & 17,40 \\
\hline
\end{tabular}

Hasil pengeringan menunjukkan, kadar air simplisia tempuyung dari ketiga cara pengeringan dapat memenuhi standar mutu yaitu berkisar antara 6,67-8,80\%. Sedangkan rendemen simplisia tertinggi adalah sebesar 17,40\% hasil dari pengeringan menggunakan alat dan terkecil 10,60\% dengan pengeringan matahari. Untuk kadar abu dari ketiga cara pengeringan tidak berbeda jumlahnya berkisar antara $13,12-14,93 \%$.

Mutu simplisia tempuyung yang dikeringkan dengan memanfaatkan sinar matahari, matahari ditutup dengan kain hitam maupun menggunakan alat pengering tidak berbeda (Tabel 1). Hasil pengamatan menunjukkan kadar sari air lebih besar dibandingkan kadar sari alkohol, masing-masing 
berkisar antara 26,73-28,16\% dan 6,77-9,01\%. Dengan demikian untuk mengekstrak tempuyung dapat dilakukan dengan menggunakan pelarut air ataupun campuran antara air dengan etanol.

Hasil penapisan fitokimia secara kualitatif diperoleh, simplisia tempuyung mengandung senyawa golongan flavonoid, alkaloid, tannin, saponin, triterfenoid, steroid dan glikosida (Tabel 2). Menurut Katno (2004), senyawa aktif yang terdapat pada tempuyung termasuk golongan flavonoid berbentuk glikosida yaitu apigenin 7-glukosida dan luteolin 7-glukosida.

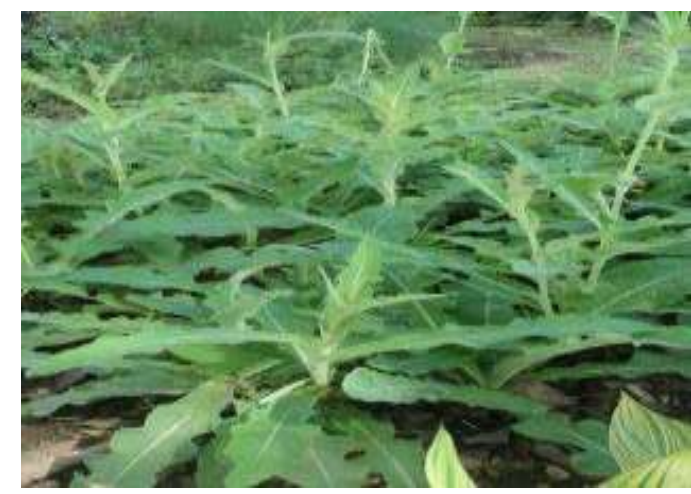

Gambar 1. Tanaman Tempuyung (Sonchus arvensis L.)

Tabel 2. Hasil skrining fitokimia simplisia tempuyung

\begin{tabular}{lccc}
\hline \multirow{2}{*}{ Uji Fitokimia } & \multicolumn{3}{c}{ Hasil } \\
\cline { 2 - 4 } & Matahari & Matahari ditutup kain hitam & Alat \\
\hline Alkaloid & + & + & + \\
Tanin & + & + & + \\
Saponin & + & + & + \\
Fenolik & - & - & - \\
Flavonoid & + & + & + \\
Triterfenoid & + & + & + \\
Steroid & + & + & + \\
Glikosida & + & + & + \\
\hline
\end{tabular}

\section{Rendemen Ekstrak Tempuyung}

Rendemen ekstrak tempuyung yang dihasilkan berkisar antara 6,8-9,1\%. Hasil tertinggi diperoleh dari perlakuan ukuran partikel 40 mesh dan lama ekstraksi 2 jam dan terkecil pada perlakuan ukuran bahan 20 mesh dan lama ekstraksi 2 jam. Semakin lama waktu ekstraksi, rendemen ekstrak yang diperoleh semakin besar (Gambar 2).

Gambar 1. Histogram rendemen ekstrak tempuyung 
Feri Manoi: Pengaruh Kehalusan Bahan Dan Lama Ekstraksi Terha dap Mutu Ekstrak Tempuyung

Tabel 3. Pengaruh ukuran bahan dan lama ekstraksi terhadap rendemen dan mutu ekstrak tempuyung

\begin{tabular}{cccccc}
\hline \multirow{2}{*}{ Ukuran Bahan } & \multirow{2}{*}{ Lama Ekstraksi } & \multicolumn{3}{c}{ Rendemen Ekstrak } & \multirow{2}{*}{ Rata-rata } \\
\cline { 2 - 5 } & & UL I & UL II & UL III & 6,58 \\
\multirow{2}{*}{20 mesh } & 2 jam & 6,64 & 6,52 & 6,58 & 7,80 \\
& 4 jam & 7,79 & 8,00 & 7,61 & 8,30 \\
& 6 jam & 8,25 & 3,36 & 8,34 & 9,10 \\
\multirow{3}{*}{40 mesh } & 2 jam & 9,10 & 9,00 & 9,20 & 8,96 \\
& 4 jam & 8,93 & 8,96 & 8,99 & 8,35 \\
& 6 jam & 8,40 & 8,30 & 8,35 & 8,86 \\
& 2 jam & 8,98 & 8,75 & 8,85 & 8,86 \\
& 4 jam & 8,95 & 8,87 & 8,76 & 8,97 \\
\hline
\end{tabular}

Mardina (2011) semakin lama waktu ekstraksi, semakin tinggi rendemen yang diperoleh karena kesempatan bereaksi antara bahan dengan pelarut semakin lama sehingga proses penetrasi pelarut kedalam sel bahan semakin baik yang menyebabkan semakin banyak senyawa yang berdifusi keluar sel. Menurut Heath dan Reineocius (1986), semakin kecil ukuran bahan yang digunakan maka semakin luas bidang kontak antara bahan dengan pelarut dan semakin besar kecepatan mencapai kesetimbangan system. Jaringan bahan/ simplisia dapat mem-pengaruhi efektivitas ekstraksi. Ukuran bahan yang sesuai akan menjadikan proses ekstraksi berlangsung dengan cepat sehingga tidak memakan waktu yang lama. Lama ekstraksi 2 jam dan ukuran partikel bahan 40 mesh menghasilkan rendemen ekstrak tertinggi yaitu sebesar $9,1 \%$.

\section{Mutu Ekstrak}

Tanaman tempuyung mengandung unsur mineral, antara lain adalah silika, kalium, magnesium, natrium, dan senyawa organik seperti flavonoid (kaempferol, luteolin-7-Oglukosida, dan apigenin-7-O-glukosida), kumarin (skepoletin), taraksasterol, inositol, serta asam fenolat (sinamat, kumarat, dan vanilat). Kandungan flavonoid total di dalam daun tempuyung sebesar 0.104\% (Chairul, 1999). Ekstrak tempuyung dapat memecah batu ginjal dan batu saluran kencing (Winarto, 2004). Flavonoid terkandung di dalam S. arvensis yang diduga kuat sebagai senyawa bioaktif antikanker. Mekanisme penghambatan sel kanker oleh flavonoid adalah dengan menduduki tempat pengikatan adenosin trifosfat (ATP) dari protein kinase, sehingga menurunkan aktivitas protein kinasenya. Protein kinase merupakan enzim yang berperan penting dalam transduksi sinyal yang memacu siklus perbanyakan pada sel-sel kanker (Hanahan \& Weinberg 2000).

\section{KESIMPULAN}

Kadar sari air tempuyung lebih tinggi dibandingkan kadar sari alkohol. Mutu simplisia tempuyung antara pengering matahari dan alat tidak berbeda kadarnya. Lama ekstraksi berpengaruh terhadap rendemen ekstrak demikian juga dengan ukuran partikel bahan.

\section{DAFTAR PUSTAKA}

Anonim. 2008. Daftar Obat Alam (DOA). Ikatan Sarjana Farmasi Indonesia (ISFI) dan Gabungan Pengusaha Jamu dan Obat Tradisional. Jawa Tengah. 202 hal. 
Badan Pengawasan Obat dan Makanan. 2006. Monograf Ekstrak Tanaman Obat Indonesia. Jakarta.

Baher, Z.F., M. Mirza, M. Ghorbanli and M.B. Rezaii. 2002. The influence of water stress on plant height, herbal and essential oil yield and composition in Satureja hortensis L. Flavour \& Fragrance J., 17 (4) : 275-277.

Chairul. 1999. Tempuyung untuk Menghadang Asam urat. www. indomedia. com/intisari/1999/juni/tempuyung.htm [21 Mei 2007].

Eisai, P.T. 2000. Indek tumbuh-tumbuhan obat Indonesia. PT. Eisai Indonesia, Jakarta. 348 hal.

Heyne, K. 1987. Tumbuhan Berguna Indonesia (Terjemahan). Badan Litbang Kehutanan, Jakarta.

Jafarsidik, Y. 1999. Inventory of traditional therapy and medicinal plants in several localities in Indonesia. The second meeting of the Asean Expert group on herbal and medicinal plants. Cisarua, Bogor 13-15 Juli 1999.

Joanne, B., Linda, A.A., Philipson, J.D. 2007. Herbal medicines $3^{\text {th }}$ edition, Pharmaceutical Press, 574576.

Joanne, B., Linda, A.A., Philipson, J.D. 2007. Herbal medicines $3^{\text {th }}$ edition, Pharmaceutical Press, 574576.

Ma'at, S. 2001. Manfaat Tanaman Obat Asli Indonesia Bagi Kesehatan. Prosiding Forum Koordinasi Kelembagaan Produksi Aneka Tanaman. Jakarta 13-16 November 2001.

Rivai, M.A., dan Y. Anggadiredja. 1995. Keanekaragaman plasma nutfah tanaman obat Indonesia. Penanganan Penelitian, Pengembangan, dan Pelestariannya. Seminar Keanekaragaman Hayati Tumbuhan Obat Tropika. PPOT-UGM. 10 hal.

Siswanto, Y.W. 2004. Penanganan Hasil Panen Tanaman Obat Komersial. Penebar Swadaya. Jakarta

Spelman, K., Burns, J.J., Nichols, D., Winters, N., Ottersberg, S. and Tenborg, M. 2006. Modulation of cytokine expression by tradisional medicines: a review of herbal immunomodulators. Alternative Medicine Review (11): 128-146

Trihono. 2011. Regulasi penggunaan jamu untuk terapi kedokteran modern. Prosiding Simposium Penelitian Bahan Obat Alami XV di Solo, 9-10 November 2011.

WHO. 1999. Monographs on Selected medicinal Plants. Vol. 1. Geneva. 365 p. 